istry, McGill University, Montreal, Canada, where, in collaboration with Prof. Harold Hibbert, he examined the structure of certain bacterial polysaccharides. He went to the United States in 1930 to become a research assistant to Dr. P. A. Levene on the staff of the Rockefeller Institute for Medical Research, New York, and in 1926 was promoted to the position of research associate. Dr. Carlson was born in Lincoln, Nebraska, in 1913. He pursued his early professional education at the University of Nebraska, from which he obtained the degree of B.S. in chemistry in 1933 and the degree of II.S. in the same field in 1935. A littlo more than a year was spent at the Iowa State College in biophysical chem. istry, after which he transferred to the Ohio State University. At the latter institution he held a research fellowship in the Industrial Research Foundation, receiving the degree of Ph.D. in March 1939 with a thesis entitled "Physiological Studies on the Synthesis of Dextran by Bacteria of the Genus Leuconostoc".

\section{Mathematical Tables}

The Works Progress Administration of the City of New York is undertaling extensive computation of mathematical tables. The work is sponsored by Dr. L. J. Briggs, director of the National Bureau of Standards, and is intended to give employment to clerical workers in New York. Several tables, including Bessel functions for complex arguments, exponential and trigonometric integrals, and the error function are completed or in active progress. Of the tables under consideration, the most noteworthy is a table of elliptic functions for complex arguments so designed as to cover a period parallelo. gram in each case.

\section{Recent Sunspots}

Two very large groups of sunspots have recently appeared. 'The first of these was a big single spot with companions increasing in size; the second group comprised a complex stream. Positions and areas are as follows :

$\begin{array}{cccc}\text { Date on disk } & \begin{array}{c}\text { Central meridian } \\ \text { passage }\end{array} & \text { Latitude } & \begin{array}{c}\text { Jaximum } \\ \text { arca }\end{array} \\ \text { Aug. 23-Sept.7 } & \text { Sept. 1.0 } & \mathbf{1 5}^{2} \mathrm{~S} & 3000 \\ \text { Sept.4-Sept.17 } & \text { Sept. } 10.5 & \mathbf{1 5}^{\circ} \mathrm{S} & \mathbf{2 5 0 0}\end{array}$

The areas are corrected for foreshortening and are expressed in millionths of the sun's visible hemisphere. An extensive bright eruption associated with the second group was observed at Greenwich on September 8 from $11 \mathrm{~h}$. $35 \mathrm{~m}$. until about $12 \mathrm{~h}$. $30 \mathrm{~m}$., the maximum being at $11 \mathrm{~h} .43 \mathrm{~m}$. U.T.

\section{Announcements}

THE printed addresses prepared in connexion with the Dundee meeting of the British Association, which include the presidential address by Sir Albert Seward, the addresses of sectional presidents, the first British and American Association Lecture, by Dr. Isaiah Bowman, on "Science and Social Pioneering", and Sir Richard Gregory's address as chairman of the Division for the Social and International
Relations of Science entitled "Contacts of Religion and Science", can be obtained, temporarily, from the British Association, Down House, Downe, Farnborough, Kent, price 6d. each.

OwIxg to the outbreak of war, it has been necessary to postpone indefinitely the general discussion arranged by the Faraday Society on "The Electric Double Layer", which was to have been held September 25-27. It is at present hopsd to publish tho papers in an early issue of the Transactions.

The National Emergency Blood Transfusion Service announces that registered blood donors in London and Greater London will be notified when they are required, and until then they need take no action. Donors having group $O$ blood will be called upon first for blood to be stored for national use.

THe Joint Tuberculosis Council will hold a courş in radiology at Shire Hall, Castle Hill, Cambridge, during September 20-22. A course in the diagnosis and treatment of pulmonary tuberculosis will bo held at the Tuberculosis Office, 352 Oxford Street, Manchester, during October 10-14. Further informa. tion can be obtained from Dr. J. B. McDougall, Preston Hall, near Maidstone.

Prof. Albrecht Schmidt of Frankfort-on-Main and Prof. Johannes Stark, of the PhysikalischTechnischen Reichsanstalt, Berlin-Charlottenburg, have been awarded the Goethe Medal for Art and Science, and Dr. Karl Frik, director of the Werner Siemens Institute for Radiology in the Robert Koch Hospital in Berlin, has been awarded tho Rieder Medal by the German Röntgen Society.

Dr. George W. Corser, professor of anatomy, University of Rochester School of Medicine, New York, has been appointed editor of the American Journal of Anatomy in succession to the late Dr. Charles R. Stockard.

THE issue of the Medical Journal of Australia for July 1 is a silver jubilee number containing articles on the progress of medicine, surgery, preventive medicine and medical journalism during the last twenty-five years.

As institute for research in rural hygiene has recently been set up in a farmhouse at Lichtenstein in Bavaria, the birthplace of Max von Pettenkofer, the founder of experimental hygiene in Germany.

THE seventh International Congress on Rheumatism will be hold in New York, Philadelphia and Boston during June 1-10, 1910. Further information can bo obtained from the Ligue internationale contre le rhumatisme, Keizergracht 489 , Amsterdam.

Accordra to official statistics, the population of Japan on October 1, 1938, was 72,227,700, or 969,000 more than in the previous year. Tokyo is the most populous city with $6,457,000$ inhabitants. 